\title{
SINTESIS SINAMIL BENZOAT MELALUI REAKSI ESTERIFIKASI ANTARA BENZOIL KLORIDA DAN SINAMIL ALKOHOL HASIL REDUKSI SINAMALDEHIDA
}

\author{
(THE SYNTHESIS OF CINNAMYL BENZOATE THROUGH ESTERIFICATION \\ REACTION BETWEEN BENZOYL CHLORIDE AND CINNAMYLALCOHOL REDUCED \\ FROM CINNAMALDEHYDE)
}

\author{
Maghisya Tri Oktanni dan C. Budimarwanti \\ Fakultas Matematika dan Ilmu Pengetahuan Alam Universitas Negeri Yogyakarta \\ Jl. Colombo No. 1 Yogyakarta \\ e-mail: cornelia_budimarwanti@uny.ac.id
}

\begin{abstract}
Abstrak
Penelitian ini bertujuan untuk mensintesis senyawa sinamil benzoat melalui reaksi esterifikasi antara asam asetat dengan sinamil alkohol hasil reduksi sinamaldehida. Penelitian dimulai dengan mereduksi sinamaldehida menjadi sinamil alkohol meng-gunakan reduktor $\mathrm{NaBH} 4$ pada suhu kamar. Hasil reduksi sinamaldehida direaksikan dengan benzoil klorida melalui reaksi esterifikasi menggunakan piridina pada suhu kamar selama 4 jam. Senyawa hasil reduksi sinamaldehida dan hasi reaksi esterifikasi diidentifikasi dengan menggunakan KLT, spektrofotometer IR, dan spektrofotometer GC-MS. Hasil penelitian menunjukkan bahwa reduksi sinamaldehida menghasilkan cairan berwarna kuning jerami yang mengandung sinamil alkohol dengan kadar $81,31 \%$ dan rendemen 63,94\%. Hasil reaksi esterifikasi antara benzoil klorida dan sinamil alkohol menghasilkan cairan cokelat yang mengandung sinamil benzoat dengan kadar 12,44\% dan rendemen 5,78\%.
\end{abstract}

Kata kunci: reduksi, sinamil alkohol, esterifikasi, sinamil benzoat

\begin{abstract}
This studywas aimedat synthesizing cinnamylbenzoate throughesterification reaction between benzoyl chloride and cinnamyl alcohol reduces from cinnamaldehyde. This study was started by reducing cinnamaldehyde to cinnamyl alcohol using $\mathrm{NaBH} 4$ reductor at room temperature. The reduction product of cinnamaldehyde was reacted using benzoyl chloride through esterification reaction using pyridine at room temperature for 4 hours. The product of cinnamaldehyde reduction and esterification reaction were characterized using TLC, IR spectrometer, and GC$M S$ spectrometer.The results show that the reduction of cinnamladehyde produced yellow liquor that contain cinnamyl alcohol contained $81.31 \%$ and $63.94 \%$ randemen. While the result of esterification reaction between benzoyl chloride and cinnamyl alcohol produced brown liquor that contained cinnamyl benzoate contained $12.44 \%$ and $5.78 \%$ randemen.
\end{abstract}

Keywords: reduction, cinnamyl alcohol, esterification, cinnamyl benzoate 


\section{PENDAHULUAN}

Minyak atsiri atau yang dikenal sebagai minyak eteris (aetheric oil) adalah kelompok besar minyak nabati yang merupakan bahan dasar dari wangi-wangian atau minyak gosok. Dalam perdagangan minyak atsiri dikenal sebagai bibit minyak wangi (Haris, 1987, p. 1). Usaha untuk meningkatkan nilai tambah minyak atsiri yaitu dengan mengisolasi komponen-komponen penyusunnya dan kalau memungkinkan diubah menjadi turunannya yang lebih berguna. Salah satu golongan zat aktif tabir surya adalah senyawa turunan sinamat (Finnen, 1987).

Sinamaldehida merupakan komponen utama minyak kayu manis (Guenther, 1990, p. 1). Sinamaldehida merupakan senyawa yang memiliki gugus fungsi aldehida dan alkena terkonjugasi cincin benzena. Penelitian Ping, Zhang, dan Ren (2010) menyebutkan bahwa minyak kayu manis memiliki efek antidiabetes pada tikus, sedangkan komponen yang terkandung dalam minyak kayu manis adalah sinamaldehida (42-75\%), sinamil asetat, karyofilen, linalool, dan eugenol. Sinamaldehida yang terkandung dalam minyak kayu manis bermanfaat sebagai antidiabetes (Adiwibowo \& Ngadiwiyana, 2006).

Sinamaldehida memiliki gugus fungsional aldehida, maka dapat dilakukan reaksi reduksi menggunakan reduktor, misalnya dengan $\mathrm{NaBH}_{4}$ atau dengan $\mathrm{LiAlH}_{4}$ menjadi sinamil alkohol. Terdapat dua bentuk konformasi dari struktur sinamaldehida yaitu trans-sinamaldehida dan cis-sinamaldehida (Egawa, Matsumoto, Yamamoto, \& Takeuchi, 2008). Sinamil alkohol merupakan suatu senyawa organik yang memiliki gugus fungsi - $\mathrm{OH}$ dan apabila direaksikan dengan suatu asil halida dengan bantuan piridina melalui reaksi esterifikasi akan menghasilkan suatu senyawa ester (Fessenden, 1986, p. 87). Sinamil benzoat merupakan senyawa antimycotic yang disintesis dari reaksi esterifikasi antara benzoil klorida dengan sinamil alkohol dengan bantuan piridina dan hasilnya cairan berwarna oranye yang mempunyai titik didih $37^{\circ} \mathrm{C}$ (Koga, Matsuse, Teramoto, \& Ueda, 1993).

Penelitian ini bertujuan untuk mensintesis senyawa sinamil alkohol dari reduksi sinamaldehida dengan menggunakan natrium borohidirda dan mensintesis senyawa sinamil benzoat melalui reaksi esterifikasi senyawa sinamil alkohol hasil reduksi sinamaldehida dengan benzoil klorida. Hasil reaksi reduksi sinamaldehida dan reaksi esterifikasi yang diperoleh diidentifikasi dengan KLT, spektroskopi IR, dan spektroskopi GC-MS.

\section{METODE}

Alat yang digunakan dalam penelitian ini adalah spektrofotometer GC-MS Shimadzu QP-2010S, spektrofotometer IR 
Shimadzu 8201PC, satu set alat refluks, satu set alat KLT, neraca analitik, spatula, aluminium foil, kertas saring, dan alat-alat gelas laboratorium.

Bahan yang digunakan dalam penelitian ini adalah sinamaldehida p.a. Merck, benzoil klorida Em.801804, piridina p.a Merck, etanol absoult p.a. Merck, $\mathrm{NaBH}_{4}$ p.a Merck, dietil eterp.a. Merck, $\mathrm{HCl}$ p.a Merck, $\mathrm{CH}_{2} \mathrm{CL}_{2}$ p.a. Merck, $\mathrm{CaCl}_{2}$ p.a Merck, Akuades, dan plat KLT Merck Si gel $60 \mathrm{GF}_{254}$.

Penelitian ini dilakukan melalui dua tahap. Tahap pertama, sintesis sinamil alkohol dari reduksi sinamaldehida menggunakan natrium borohidrida. Tahap kedua, sintesis sinamil benzoat dari reaksi esterifikasi sinamil alkohol hasil reduksi sinamaldehida dengan benzoil klorida

Sinamaldehida sebanyak 10,56 gram (0,08 mol) dimasukkan ke dalam labu leher tiga $250 \mathrm{~mL}$ yang dilengkapi dengan water bath dan pengaduk magnet. Sebanyak 0,76 gram $(0,02 \mathrm{~mol}) \mathrm{NaBH}_{4}$ dilarutkan dalam 40 $\mathrm{mL}$ etanol absolut dan dimasukkan ke dalam labu leher tiga. Campuran diaduk selama 40 menit menggunakan magnetic stirrer pada suhu kamar. Kemudian campuran diasamkan dengan $\mathrm{HCl} 6 \mathrm{M}$ disertai pengadukan sampai $\mathrm{pH}=4,5$. Campuran kemudian disaring sehingga didapatkan residu dan filtrat. Filtrat yang diperoleh kemudain diekstraksi tiga kali, masing-masing menggunakan $\mathrm{CH}_{2} \mathrm{Cl}_{2}$ sebanyak $15 \mathrm{~mL}$. Fasa organik dikeringkan dengan $\mathrm{CaCl}_{2}$ kemudian disaring. Filtrat disimpan untuk dilakukan karakterisasi.

Sebanyak 2,03 gram $(0,015 \mathrm{~mol})$ hasil reduksi sinamaldehida dan 2,11 gram $(0,015$ mol) benzoil klorida dimasukkan dalam labu leher tiga yang dilengkapi dengan magnetic stirrer, campuran diaduk selama 20 menit pada suhu kamar. Kemudian dimasukkan tetes demi tetes piridina sebanyak $5 \mathrm{~mL}$, campuran direfluk selama 4 jam. Setelah refluk selesai, kemudian campuran tersebut ditambahkan dietil eter $3 \mathrm{~mL}$ dan akuades 3 mL dan diekstraksi. Campuran tersebut akan membentuk dua lapisan. Lapisan bagian atas diambil dan diekstraksi kembali dengan akuades $3 \mathrm{~mL}$ sebanyak 3 kali. Kemudian dimasukkan kedalam rotary evaporator dan setelah selesai hasilnya disimpan untuk di lakukan identifikasi.

\section{HASIL DAN PEMBAHASAN}

Data hasil reaksi reduksi sinamaldehida dengan menggunakan $\mathrm{NaBH}_{4}$ disajikan pada Tabel 1. Tabel 1 menunjukkan terdapat perbedaan nilai $\mathrm{Rf}$ sinamaldehida dengan nilai $\mathrm{Rf}$ hasil reduksi sinamaldehida, nilai Rf hasil reduksi sinamaldehida lebih kecil dari Rf sinamaldehida, karena berdasarkan kepolarannya senyawa aldehida lebih nonpolar daripada senyawa alkohol. Senyawa yang lebih polar akan terikat pada fasa diam (plat KLT) sehingga memiliki nilai Rf lebih kecil. 
Tabel 1

Data Hasil Reduksi Sinamaldehida

\begin{tabular}{lc}
\hline \multicolumn{1}{c}{ Data } & Hasil \\
\hline Bau & Harum \\
Warna & Kuning Jerami \\
Berat & 8,43 gram \\
Wujud & Cair \\
Nilai Rf 1 (noda sinamaldehida) & 0,84 \\
Nilai Rf 2 (noda hasil reduksi sinamaldehida) & 0,55 \\
\hline
\end{tabular}

Hasil Spektrum IR senyawa hasil reduksi sinamaldehida ditunjukkan pada Gambar 1.
Berdasarkan spektrum IR senyawa hasil reduksi sinamaldehida menunjukkan serapan melebar dengan puncak di daerah

Gambar 1. Spektrum IR Senyawa Hasil Reduksi Sinamaldehida

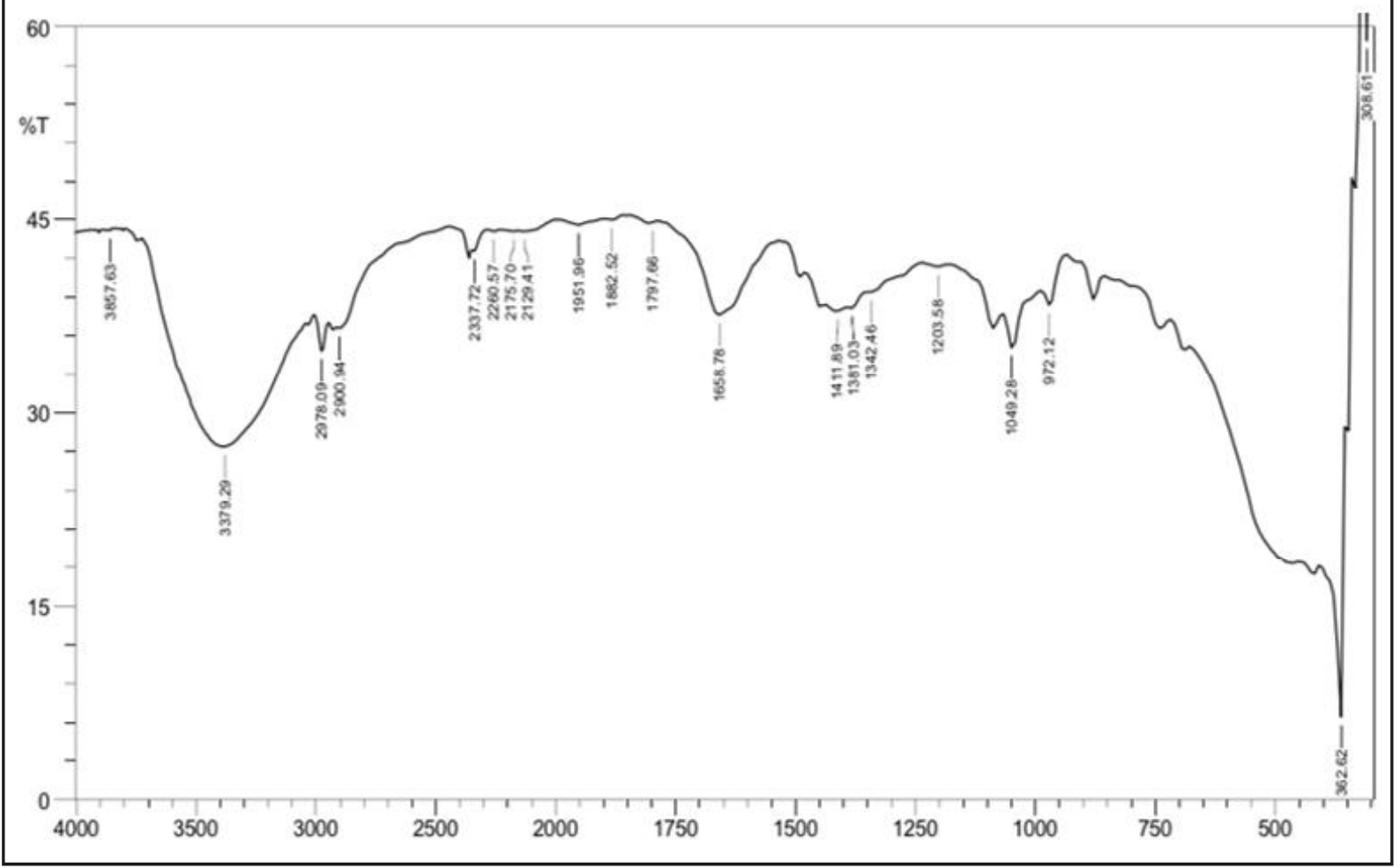


$3379 \mathrm{~cm}^{-1}$ yang merupakan serapan gugus -OH, dan tidak muncul serapan di daerah $2816,64 \mathrm{~cm}^{-1}$ dan 2743,56 $\mathrm{cm}^{-1}$ (dublet) yang merupakan ciri khas serapan $\mathrm{COH}$ aldehida.

Analisis spektrum IR senyawa sinamaldehida dibandingkan dengan spektrum IR hasil reduksi sinamaldehida dapat dilihat pada Tabel 2.

Hasil kromatogram GC senyawa hasil reduksi sinamaldehida ditunjukkan pada Gambar 2.

Berdasarkan kromatogram GC, senyawa hasil reduksi sinamaldehida ditunjukkan pada puncak ke-5 dengan waktu retensi 19,585 menit dengan kadar $81,31 \%$. Kemudian fragmentasi senyawa sinamil alkohol hasil reduksi sinamaldehida ditunjukkan spektrum massa pada Gambar 3.

Puncak ke-5 dalam spektrum massa ini adalah senyawa sinamil alkohol dengan $\mathrm{M}^{+}$ 134. Base peak dari spektrum tersebut yaitu 92 karena distabilkan oleh elektron yang beresonansi pada cincin benzena.

Fragmentasi senyawa sinamil alkohol sebagai berikut.
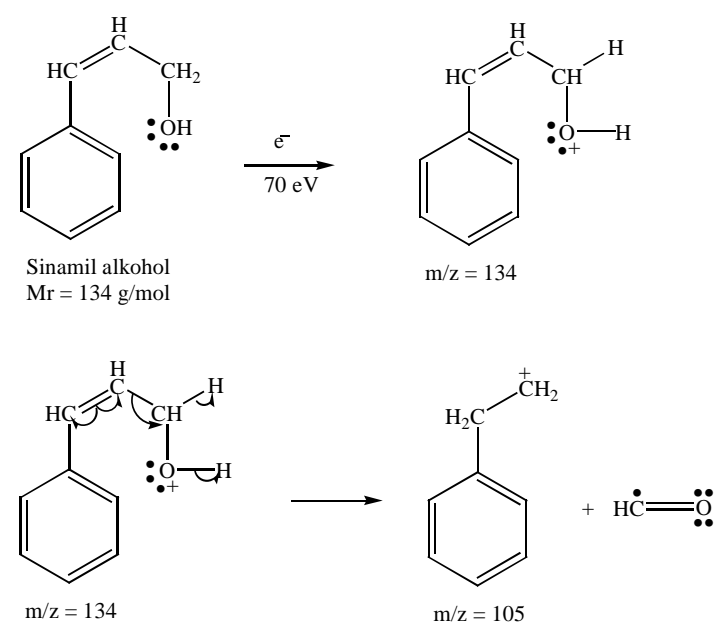

Tabel 2

Daerah Serapan IR Senyawa Sinamaldehida dan Hasil Reduksi Sinamaldehida

\begin{tabular}{|c|c|c|}
\hline \multicolumn{2}{|c|}{ Bilangan Gelombang $\left(\mathrm{cm}^{-1}\right)$} & \multirow[b]{2}{*}{ Gugus Fungsi } \\
\hline Sinamaldehida & $\begin{array}{l}\text { Hasil Reduksi } \\
\text { Sinamaldehida }\end{array}$ & \\
\hline $\begin{array}{c}2816,64 \text { dan } 2743,56 \\
\text { (lemah) }\end{array}$ & - & C-H aldehida \\
\hline 1492,70 & 1411,89 & $\mathrm{C}=\mathrm{C}$ aromatik \\
\hline 1625,43 & 1658,78 & $\mathrm{C}=\mathrm{C}$ alkena \\
\hline - & 3379,29 (melebar) & O-H alkohol \\
\hline 3059,76 & 3857,63 & $=\mathrm{C}-\mathrm{H}$ aromatik \\
\hline- & 2900,94 dan 2978,09 & $\mathrm{C}-\mathrm{H}$ alkena \\
\hline 1676,56 (kuat) & - & $\mathrm{C}=\mathrm{O}$ karbonil \\
\hline
\end{tabular}




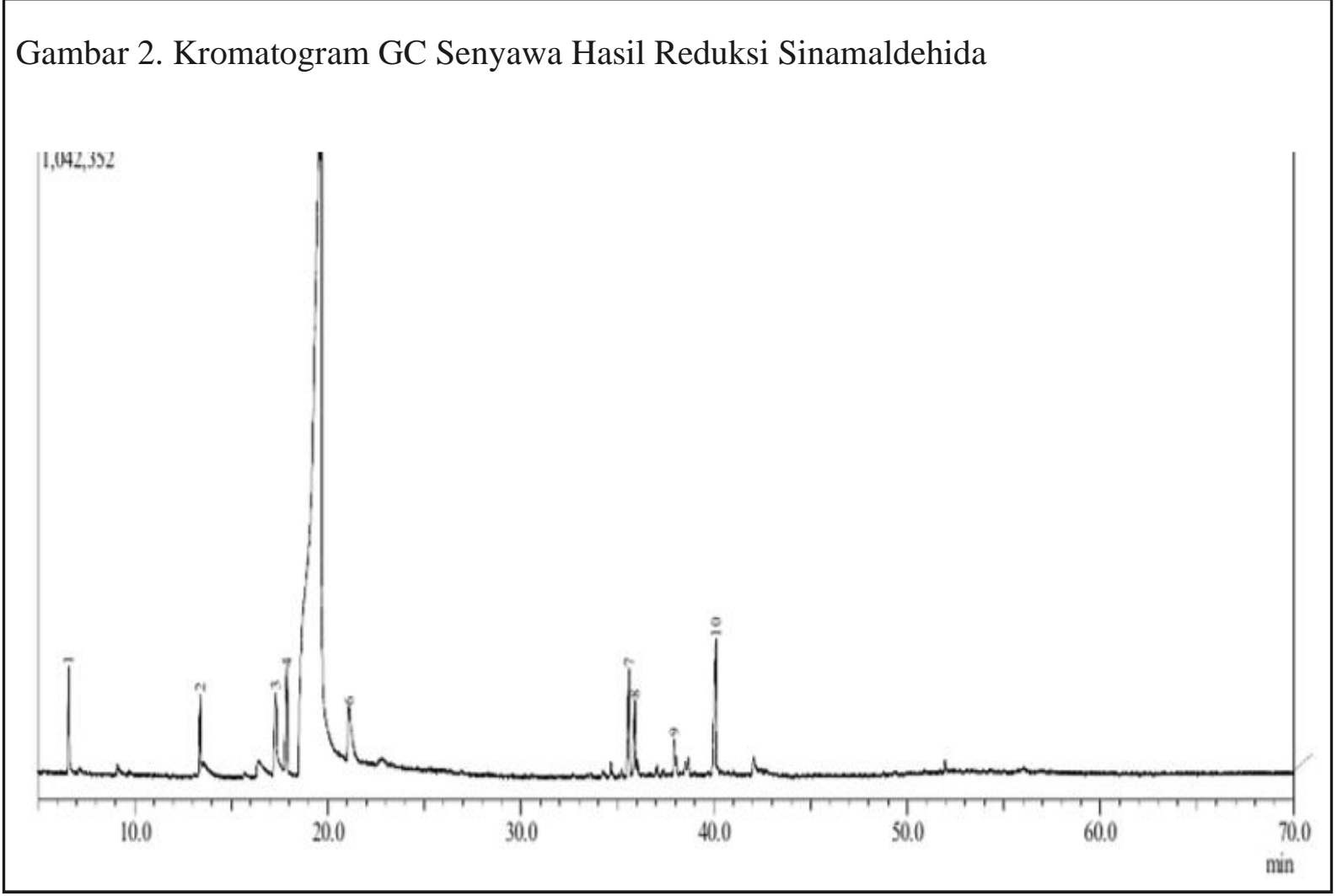

Gambar 3. Spektrum massa puncak ke-5 Senyawa Sinamil Alkohol Hasil Reduksi Sinamaldehida

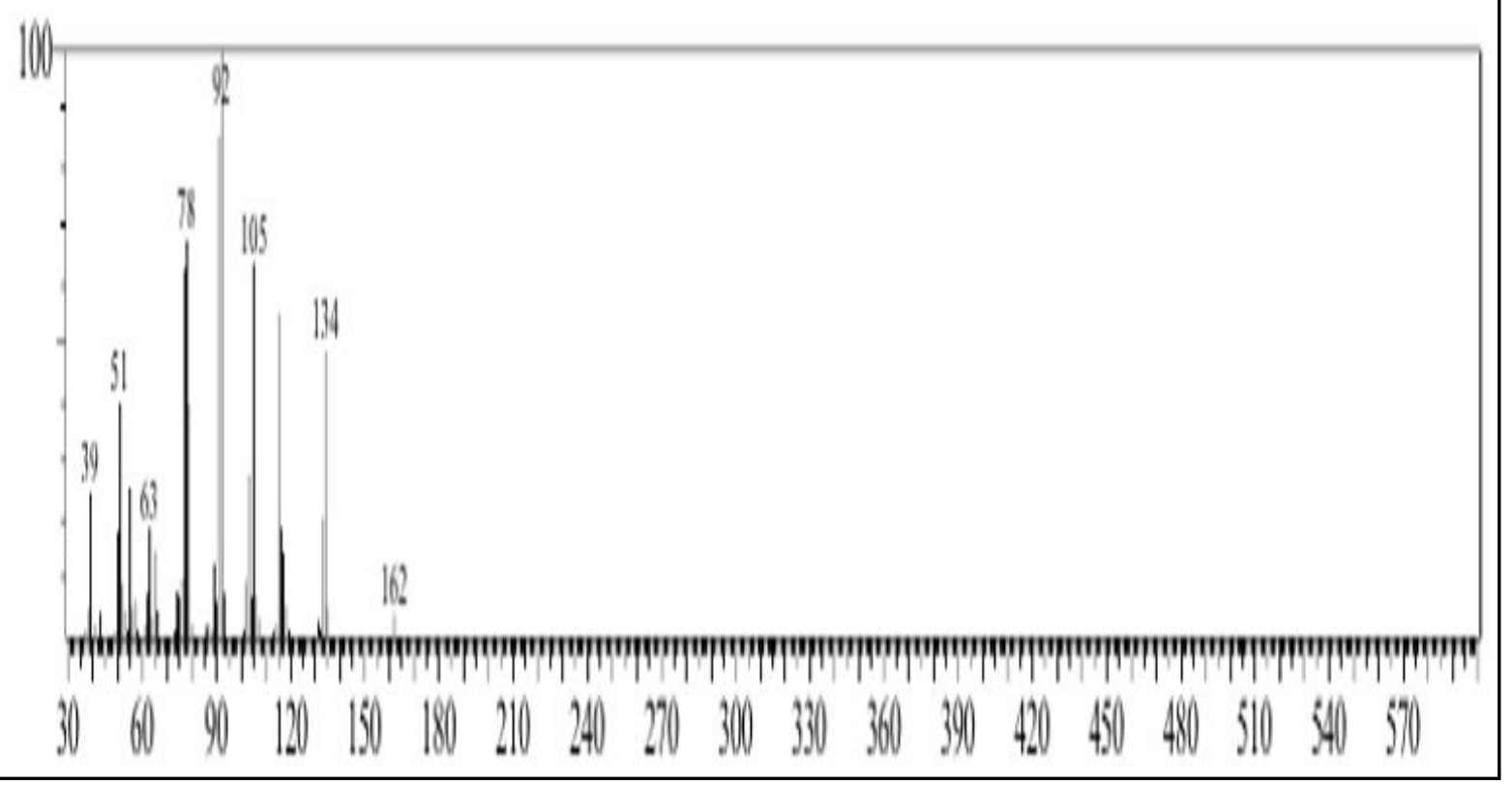




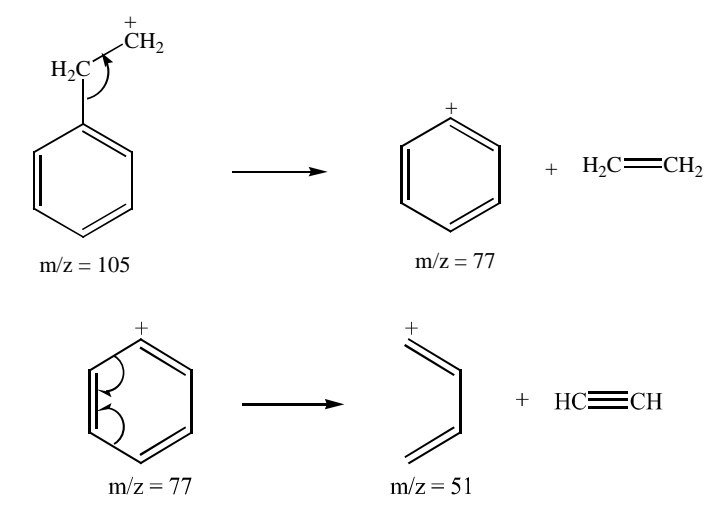

Data hasil esterifikasi antara senyawa hasil reduksi sinamaldehida dengan benzoil klorida tersaji dalam Tabel 3.

Tabel 3 menunjukkan terdapat perbedaan nilai Rf hasil esterifikasi yang lebih besar dari pada nilai Rf senyawa hasil reduksi sinamaldehida karena berdasarkan kepolarannya senyawa alkohol lebih polar daripada senyawa ester.

Hasil Spektrum IR senyawa hasil esterifikasi ditunjukkan pada Gambar 4.
Analisis hasil spektrum IR senyawa hasil esterifikasi dapat dilihat pada Tabel 4. Hasil kromatogram GC senyawa hasil esterifikasi ditunjukkan pada Gambar 5.

Berdasarkan kromatogram GC, senyawa hasil esterifikasi ditunjukkan pada puncak ke-14 dengan waktu retensi 19,249 menit dengan kadar 12,44\% . Spektrum massa senyawa puncak ke-14 yang diduga senyawa sinamil benzoat hasil esterifikasi disajikan pada Gambar 6.

Puncak ke-14 dalam spektrum massa ini adalah senyawa sinamil benzoat dengan $\mathrm{Mr} 238 \mathrm{~g} / \mathrm{mol}$. Base peak dari spektrum tersebut yaitu 105 karena terdapat $\mathrm{C}$ benzilik yaitu $\mathrm{C}$ positif yang terikat langsung pada cincin benzena. Fragmentasi senyawa sinamil benzoat sebagai berikut.

Tabel 3

Data Hasil Esterifikasi Antara Senyawa Hasil Reduksi Sinamaldehida dengan Benzoil Klorida

\begin{tabular}{lc}
\hline \multicolumn{1}{c}{ Data } & Hasil \\
\hline Bau & Menyengat \\
Warna & Cokelat \\
Berat & 1,66 gram \\
Wujud & Cair \\
Nilai Rf 1 (Noda Hasil Esterifikasi) & 0,76 \\
Nilai Rf 2 (Noda Hasil Reduksi Sinamaldehida) & 0,3 \\
\hline
\end{tabular}


Gambar 4. Spektrum IR Senyawa Hasil Esterifikasi

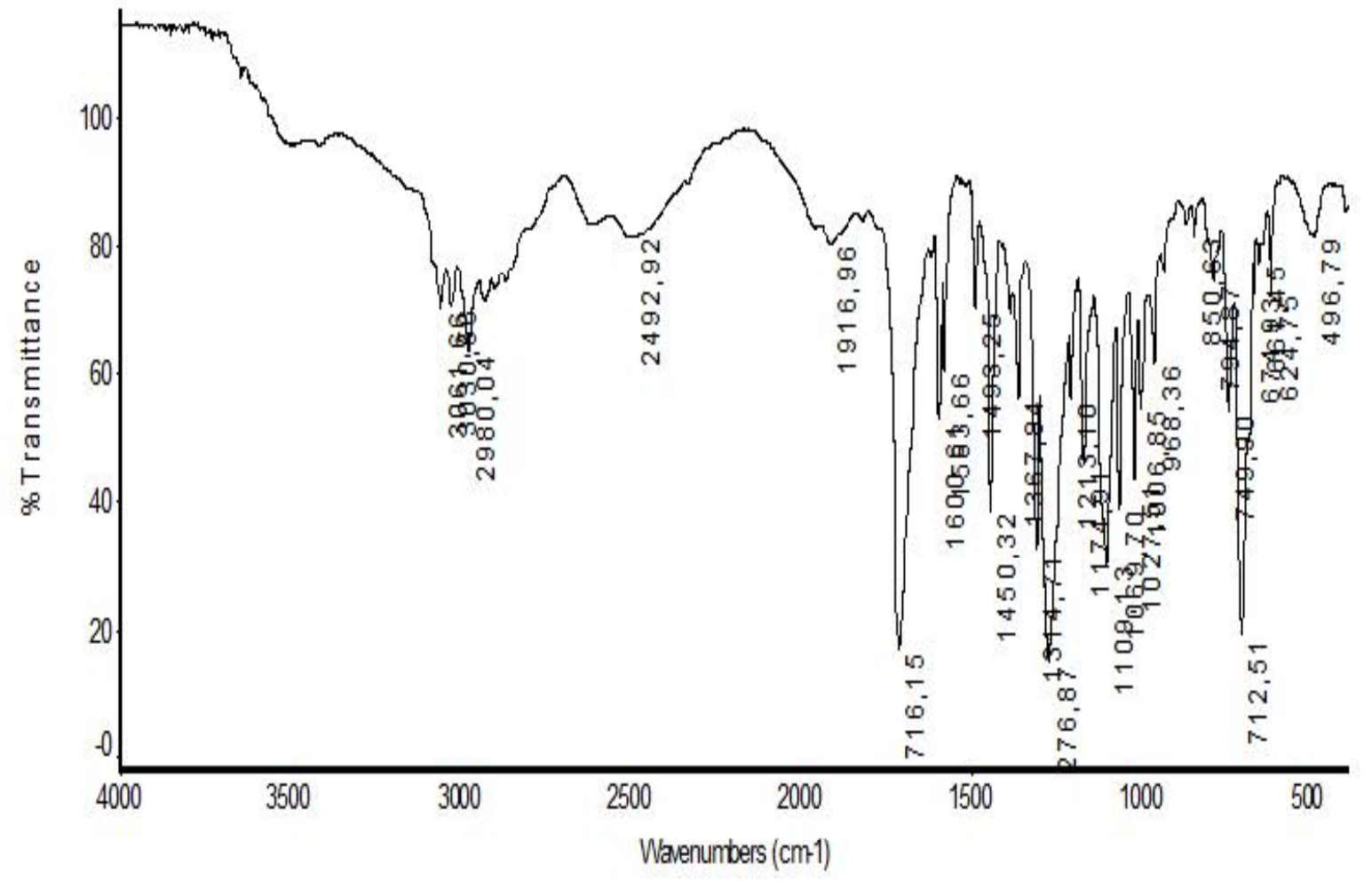

Tabel 4

Daerah Serapan Senyawa Hasil Esterifikasi pada Spektrum IR

\begin{tabular}{cc}
\hline $\begin{array}{c}\text { Bilangan Gelombang }\left(\mathrm{cm}^{-1}\right) \\
\text { Hasil Esterifikasi }\end{array}$ & Gugus Fungsi \\
\hline 1276,87 & C-O-C \\
1716,15 & $\mathrm{C}=\mathrm{O}$ karbonil \\
1450,32 & $\mathrm{C}=\mathrm{C}$ aromatik \\
1600,61 & $\mathrm{C}=\mathrm{C}$ alkena \\
3030,56 dan 3061,66 & $\mathrm{C}-\mathrm{H}$ aromatik \\
2980,04 & $\mathrm{C}-\mathrm{H}$ alkana \\
\hline
\end{tabular}


Jurnal Penelitian Saintek, Vol. 21, Nomor 2, Oktober 2016

Gambar 5. Kromatogram GC Senyawa Hasil Esterifikasi

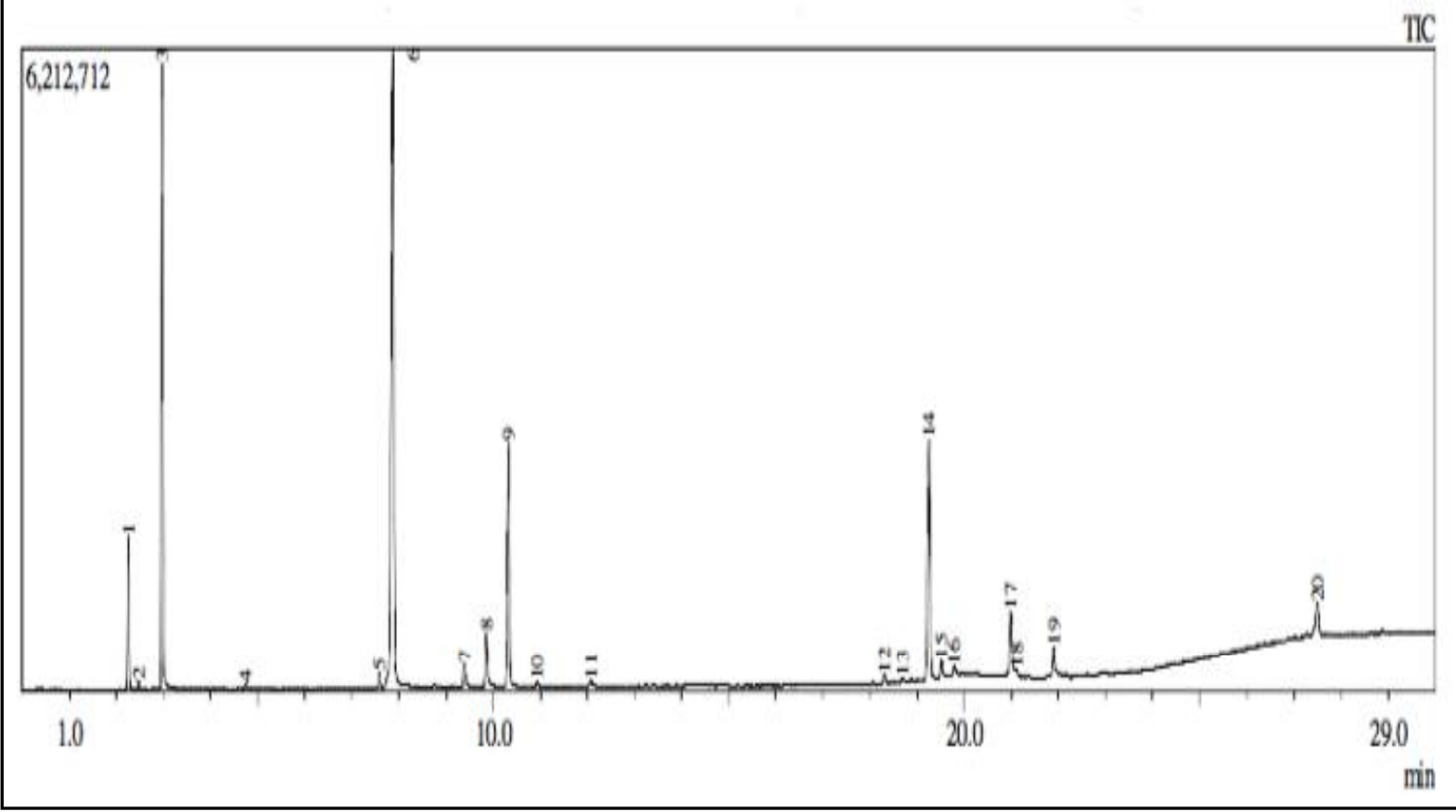

Gambar 6. Spektrum Massa Puncak ke-14 Senyawa Hasil Esterifikasi

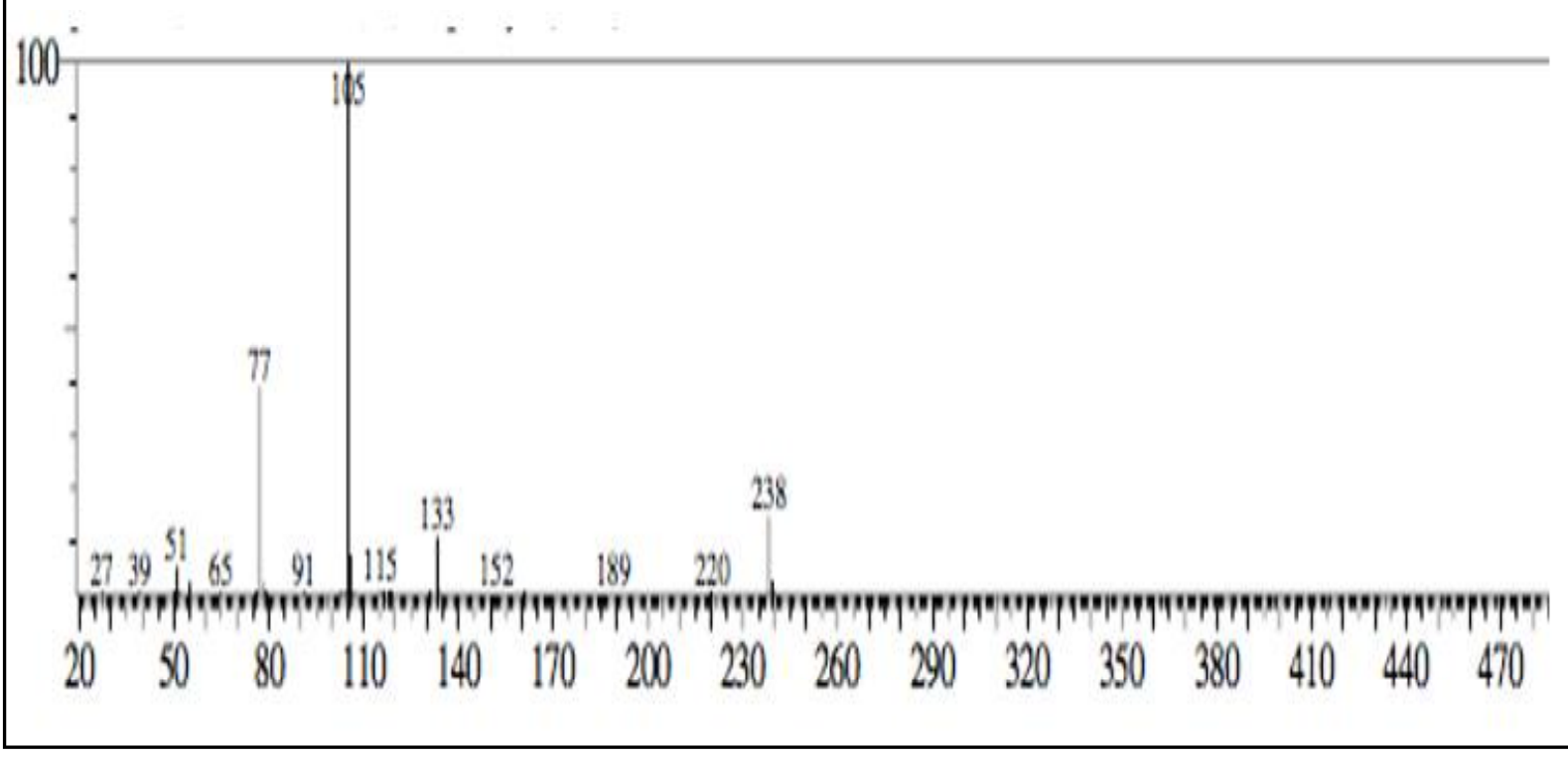


<smiles>N#[13C]C=Cc1ccccc1C=CCOC(=O)c1ccccc1</smiles><smiles>O=Cc1ccc(-c2ccccc2)cc1</smiles>

$\mathrm{m} / \mathrm{z}=105$<smiles>O=Cc1ccccc1</smiles>

$\mathrm{m} / \mathrm{z}=105$<smiles>O=[C]c1ccccc1</smiles>

$\mathrm{m} / \mathrm{z}=105$

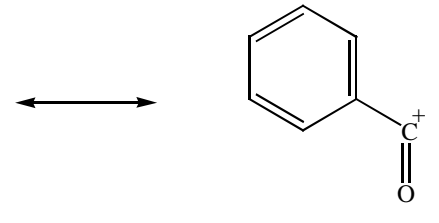

$\mathrm{m} / \mathrm{z}=105$

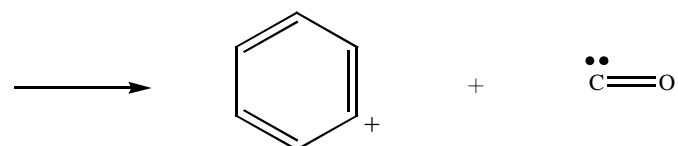

$\mathrm{m} / \mathrm{z}=77$

\section{SIMPULAN}

Berdasarkan hasil penelitian maka dapat disimpulkan bahwa reaksi reduksi sinamaldehida dengan menggunakan reduktor $\mathrm{NaBH}_{4}$ telah menghasilkan cairan berwarna kuning jerami dan berbau harum yang mengandung senyawa sinamil alkohol dengan kadar $81,31 \%$ dan rendemen sebesar 63,94\%. Reaksi esterifikasi antara benzoil klorida dan sinamil alkohol hasil reduksi sinamaldehida telah menghasilkan cairan berwarna cokelat dan berbau menyengat yang mengandung senyawa sinamil benzoat dengan kadar 12,44\% dan rendemen sebesar $5,78 \%$.

\section{DAFTAR PUSTAKA}

Adiwibawa, N. B., \& Ngadiwiyana, N. (2006). identifikasi senyawa penyusun minyak kulit batang kayu manis (cinnamomum cassia) menggunakan GC-MS. Jurnal Kimia Sains dan Aplikasi, 9(1). 
Egawa, T., Matsumoto, R., Yamamoto, D., \& Takeuchi, H. (2008). Molecular structure of trans-cinnamaldehyde as determined by gas electron diffraction aided by DFT calculations. Journal of Molecular Structure, 892(1), 158-162.

Fessenden, J. R., \& Fessenden, J. S. (1986). Kimia organik Jilid 2 (Edisi ke-3). (Terj.: A. H. Pudjatmaka). Jakarta: Erlangga.

Finnen, M. J. (1987). Skin metabolism by oxidation and conjugation. $J$. Pharmacol. Skin, 72(4), 69-88.

Guenther, E. (1990). Minyak atsiri (Jilid II). Jakarta: Penerbit Universitas Indonesia.
Haris, R. (1987). Tanaman minyak atsiri. Jakarta: Penebar Swadaya.

Koga, T., Matsuse, I., Teramoto, Y., \& Ueda, S. (1993). Synthesis and antimycotic activity of cinnamyl benzoate. Journal of Fermentation and Bioengineering, 76(6), 524-526.

Ping, H., Zhang, G., \& Ren, G. (2010). Antidiabetic effects of cinnamon oil in diabetic KK-Ay mice. Food and Chemical Toxicology, 48(8), 23442349. 